\title{
JUDICIAL DISCRETION IN SENTENCING: A JUSTICE SYSTEM THAT IS NO LONGER JUST?
}

\author{
Sean J Mallett*
}

One of the fundamental principles of the criminal law is consistency: like offenders must be treated alike. However, research has shown that when it comes to sentencing in New Zealand, there is in fact substantial regional disparity in the penalty imposed on similarly situated offenders. The situation is unacceptable, and undermines the integrity of the criminal justice system. This article will explore three different mechanisms for guiding judicial discretion in the pursuit of sentencing consistency. It will undertake an analysis of mandatory sentences and the "instinctive synthesis" approach, both of which will be shown to be unsatisfactory. Instead, the article will argue that the establishment of a Sentencing Council with a mandate to draft presumptively binding guidelines is the most appropriate way forward for New Zealand. This option finds the correct equilibrium between giving a judge sufficient discretion to tailor a sentence that is appropriate in the circumstances of the individual case, yet limiting discretion enough to achieve consistency between cases.

\section{INTRODUCTION}

\begin{abstract}
Sentencing ... is founded upon two premises that are in perennial conflict: individualized justice and consistency. The first holds that courts should impose sentences that are just and appropriate according to all of the circumstances of each particular case. The second holds that similarly situated offenders should receive similar sentencing outcomes. The result is an ambivalent jurisprudence that challenges sentencers as they attempt to meet the conflicting demands of each premise. ${ }^{1}$
\end{abstract}

Sentencing is a notoriously difficult component of the criminal law. It requires a judge to balance complex, abstract and often competing considerations with a view to achieving the elusive

* Submitted as part of the LLB(Hons) programme at Victoria University of Wellington.

1 Sarah Krasnostein and Arie Freiberg "Pursuing Consistency in an Individualist Sentencing Framework: If You Know Where You're Going, How Do You Know When You've Got There?" (2013) 76 Law and Contemp Probs 265 at 265. 
and equally abstract notion of "justice". To this end, judges have traditionally enjoyed considerable discretion to tailor an appropriate sentence, subject to the maximum penalties prescribed by Parliament. However, this flexibility comes at the cost of another important principle of the criminal law: consistency. The more discretion a judge is allowed to exercise, the greater the risk of similarly situated offenders being treated differently. How to resolve this tension and find a suitable equilibrium is a problem faced by jurisdictions the world over.

This article will examine the extent of sentencing inconsistency in New Zealand, and investigate various approaches to guiding judicial discretion in the imposition of criminal penalties. It will begin by analysing the importance of the consistency principle itself, with a particular focus on the effect parity has on public confidence in the judiciary. If similar offenders are not treated alike then the community begins to view the courts as unfair, which in turn jeopardises the ongoing legitimacy of the justice system. Ensuring that there are adequate mechanisms in place to achieve sentencing consistency is of fundamental importance to our system of law.

In New Zealand these mechanisms take two forms: the principles and purposes of sentencing found under the Sentencing Act 2002, and guideline judgments issued by the Court of Appeal. On analysis these will be shown to be inadequate. Studies have revealed that there is still substantial inconsistency in sentencing across geographic locations, particularly in relation to the less serious offences which form the bulk of the cases dealt with by the District Courts on a daily basis. The purposes and principles of sentencing set out in the Sentencing Act are too broad, and are simply a restatement of the common law position. Guideline judgments are more effective, but suffer from several systemic and constitutional limitations. Policy adjustments are clearly required, and this article will examine three different approaches that the legislature could adopt in order to achieve greater consistency in sentencing.

If the amount of discretion a judge enjoys could be placed on a spectrum, at one end would lie mandatory sentences. Mandatory sentences ensure consistency in sentencing by legislatively removing discretion entirely. However, because the facts of any given case are unique, this approach inevitably comes at the expense of individualised justice. Furthermore, the practical effect of mandatory sentences would be simply to shift discretion from the judges into the hands of police and prosecutors, as an offender's sentence would effectively be determined by the choice of charge laid. This raises issues around transparency and accountability, leading to the conclusion that the widespread implementation of mandatory sentences would cause more problems than it could potentially solve.

At the other end of the spectrum lies the "intuitive synthesis" approach, a doctrine that removes constraints on judicial discretion entirely, giving the sentencing judge a wide scope to balance the innumerable factors that make up an individual case and come to a decision that is holistically appropriate in all the circumstances. This approach has been adopted in jurisdictions in the federal systems of Australia and Canada, and is underpinned by the belief that there is no objectively "right" 
sentence. However, it will be argued that the doctrine would be a retrograde step for New Zealand, because it both masks, and in many respects normalises, disparity.

The appropriate way forward for New Zealand is to adopt a mechanism that falls within the above two extremes. Discussion will therefore turn to the implementation of a Sentencing Council, a body comprised of experts and judges with a mandate to issue presumptively binding sentencing guidelines. Such a Council exists on the statute books in New Zealand, ${ }^{2}$ but has not been established in practice. Because the body would be in a position to undertake extensive research and consultation, it can in turn provide coherence to sentencing policy as a whole, while also giving the Government enhanced control over its Corrections budget. Several constitutional issues have been raised about the existence of such a body, but these will be shown to be overstated. The only real concern is ensuring that a Council has widespread judicial support, something that is critical to its ongoing success. The article will conclude that the establishment of a Sentencing Council is the most appropriate mechanism for guiding judicial discretion and ensuring consistency within the criminal justice system.

\section{IMPORTANCE OF CONSISTENCY IN SENTENCING}

Consistency in sentencing is of fundamental importance to the criminal justice system, and has been afforded statutory recognition in New Zealand under s 8(e) of the Sentencing Act 2002. What is needed is parity: like offenders must be treated alike, a maxim that has its origins in the works of Aristotle. ${ }^{3}$ If offenders are not treated alike, then the Court of Appeal has acknowledged that the resulting disparity "can result in injustice to an accused person and may raise doubts about the evenhanded administration of justice". ${ }^{4}$ Conversely, dissimilar cases should not be treated in a like fashion. Both of these situations would lead to injustice and erode public confidence in the legal system. 5

The importance of maintaining this confidence cannot be overstated. Victims and witnesses will only cooperate with police and prosecutors if they trust the system and the professionals - including judges - with whom they have contact. ${ }^{6}$ That trust will quickly diminish if the public perceives the system to be inconsistent in its outcomes and thus unfair. The legitimacy of the criminal justice system hinges on public support, and this needs to be earned. As Professor Julian Roberts notes, a

2 Sentencing Council Act 2007.

3 See CJ Rowe and Sarah Broadie (eds) Aristotle: Nicomachean Ethics (Oxford University Press, Oxford, 2002).

$4 \quad R$ v Morris [1991] 3 NZLR $641(\mathrm{CA})$ at 645.

$5 \quad R v$ Lawson [1982] 2 NZLR 219 (CA) at 223; and Niamh Maguire "Consistency in Sentencing" (2010) 2 JSIJ 14 at 39.

6 Julian Roberts Public Confidence in Criminal Justice: A Review of Recent Trends 2004-2005 (Public Safety and Emergency Preparedness Canada, November 2004) at 1. 
central part of earning legitimacy is to maintain notions of fairness and integrity. ${ }^{7}$ Sara Benesh characterises the need for confidence slightly differently, saying that in order for the rule of law to remain operative, "citizens need to trust the institution charged with its keeping". ${ }^{8}$ Parity in sentencing underpins the rule of law, a doctrine which requires both the absence of arbitrary power and the need for fixed and predictable laws. ${ }^{9}$ The existence and imposition of inconsistent sentences makes it impossible for the citizenry to foresee the consequences of their actions.

Although consistency is an important principle in any jurisdiction that gives weight to the rule of law, its enforcement needs to be given special emphasis in those countries that maintain high levels of incarceration. This includes New Zealand, a nation that has traditionally sat at the more punitive end of the sentencing spectrum. As at 30 June 2014, New Zealand had 6,754 people serving a sentence of imprisonment, with a further 1,817 inmates on remand, ${ }^{10}$ representing an incarceration rate of approximately 190 per 100,000 of population. ${ }^{11}$ This is higher than a number of comparable jurisdictions, including Australia (170 per 100,000 as at June 2013), ${ }^{12}$ Canada (113 per 100,000 as at August 2014) and the United Kingdom (149 per 100,000 as at August 2014). ${ }^{13}$ Indeed, the only major Western nation with a higher incarceration rate than New Zealand is the United States, which tips the scales at an astonishing 707 prisoners per 100,000 of population. ${ }^{14}$ Any criminal justice system that is forced to sentence such high volumes of offenders inherently leaves itself exposed to greater levels of inconsistency.

The need for consistency is required at two levels: individual consistency in the practice of a particular judge dealing with like offenders who appear before them; but also consistency between judges generally in dealing with like cases within the same jurisdiction. ${ }^{15}$ The more cases being heard in that jurisdiction, the more difficult it is to ensure that the same sentencing practices are

7 At 16.

8 Sara Benesh "Understanding Public Confidence in American Courts" (2006) 68 J Pol 697 at 697.

9 Joseph Raz "The Rule of Law and its Virtue" in Aileen Kavanagh and John Oberdiek (eds) Arguing About Law (Routledge, London, 2009) 181 at 183.

10 Department of Corrections "Prison Facts and Statistics - June 2014" <www.corrections.govt.nz>.

11 Statistics New Zealand "National Population Estimates: At 30 June 2014" (14 August 2014) $<w w w . s t a t s . g o v t . n z>$

12 Australian Bureau of Statistics "Australian prisoner numbers reach 30,000 for the first time" (press release, 5 December 2013).

13 International Centre for Prison Studies "Highest to Lowest - Prison Population Rate" <www.prisonstudies.org>.

14 International Centre for Prison Studies, above n 13.

15 Geraldine Mackenzie "Achieving Consistency in Sentencing: Moving to Best Practice?" (2002) 22 UQLJ 74 at 75 
being followed. While we can expect a judge to be personally consistent in his or her approach to sentencing, the difficulty arises when trying to achieve consistency between adjudicators. Judges are endowed with significant discretion to tailor a sentence that is appropriate and does justice in the circumstances of the particular case. But what is an appropriate sentence? Opinions will clearly differ. Parliament is therefore left with the "significant challenge" of regulating judicial discretion in such a way that can balance the need for consistency with the reality that cases are unique and require individualised justice. ${ }^{16}$

\section{GUIDING JUDICIAL DISCRETION}

Once Parliament has prescribed the maximum penalty for an offence, judges in New Zealand do not have carte blanche to impose any sanction they see fit. They are, of course, bound by precedent. Sentences imposed must conform with those that have come before. However, given the sheer number of sentencing decisions handed down on a daily basis, relying on general precedent alone is a daunting task. Judicial discretion in this field is therefore guided by two further mechanisms: the purposes and principles set out under ss 7 and 8 of the Sentencing Act 2002; and guideline judgments issued by the appellate courts. In practice, the former provides little practical assistance, and the latter suffers from a number of systemic limitations.

\section{A Purposes and Principles of Sentencing}

In 1997, the Ministry of Justice issued a discussion paper entitled Sentencing Policy and Guidance, part of which looked at the different possible methods for guiding judicial sentencing discretion. ${ }^{17}$ It put forward a number of options ranging from mandatory sentences, ${ }^{18}$ right through to a fully comprehensive sentencing information system that would provide judges with empirical sentencing data pertaining to offence subcategories. ${ }^{19}$ The drafters of the Sentencing Act chose to implement a general statement of sentencing purposes and principles, along with a non-exhaustive list of aggravating and mitigating factors, all of which can now be found in ss 7,8 and 9 respectively of the Act. This was the loosest possible form of control on sentencing discretion that the Ministry could implement. ${ }^{20}$ The Law Commission described it as a "significant change to [the] traditional approach" to sentencing, ${ }^{21}$ although other commentators have been more reserved in their praise. ${ }^{22}$

16 Andrew von Hirsch, Andrew Ashworth and Julian Roberts (eds) Principled Sentencing: Readings on Theory and Policy (3rd ed, Hart Publishing, Portland, 2009) at 229.

17 Ministry of Justice Sentencing Policy and Guidance - A Discussion Paper (Ministry of Justice, Wellington, 1997) at [11].

18 At [11.3].

19 At [11.7.1].

20 John Ip "Sentencing Guidelines post-Sentencing Act" [2005] NZLJ 397 at 399.

21 Law Commission Sentencing Guidelines and Parole Reform (NZLC R94, 2006) at [30]. 
John Ip doubts whether the changes have had any significant effect on sentencing discretion at all, saying that: 23

Given the level of generality at which the sentencing purposes and principles are expressed, and given they can frequently suggest contradictory outcomes, it seems naïve in retrospect to have expected anything more.

This criticism is not unwarranted. Many of the sentencing principles listed in the Sentencing Act are self-evident. As Roberts rightly notes, "no judge in New Zealand... needs to be told, for example, that the maximum penalty should be imposed only for the most serious cases, although that is the direction contained in section $8(\mathrm{c}) " .{ }^{24}$ Nor do the purposes of sentencing offer any practical assistance in the application of discretion, as judges "remain free to 'pick and mix' from among the list of purposes, according to their pre-existing individual preferences". ${ }^{25}$ The result is an unusual situation whereby the sentencing judge has the discretion to choose which purpose to adopt as a means to guide their discretion - a discretion within a discretion.

Furthermore, the legislature has codified such an extensive number of sentencing rationales that they often contradict each other in practice. It is not difficult to imagine, for example, there being an inherent difficulty in imposing a sentence that provides for both the interests of the victim ${ }^{26}$ and the offender's rehabilitation and reintegration. ${ }^{27}$ Professor Geoff Hall claims that "the legislature has failed to develop a coherent sentencing policy from the theories of punishment that comprise this country's penal philosophy and jurisprudence of sentencing". ${ }^{28}$ The irony is that the Ministry of Justice explicitly acknowledged the flaws in implementing a range of equally weighted sentencing purposes and the inevitable problems they would cause in the discretionary environment in which they have to operate. ${ }^{29}$ The rationale for implementing them anyway was that "no one sentencing goal on its own provides a sufficient basis on which to provide a coherent and comprehensive sentencing regime", because which purpose to invoke is dependent on the individual circumstances of the offence and the offender. ${ }^{30}$ This may be true, but it incorrectly assumes that there are only

22 See Julian Roberts "Sentencing Reform in New Zealand: An Analysis of the Sentencing Act 2002" (2003) Australia and New Zealand Journal of Criminology 249.

23 John Ip "Sentencing Reform" [2007] NZLJ 9 at 10.

24 Roberts, above n 22, at 257.

25 At 256

26 Sentencing Act 2002, s 7(1)(c).

27 Section 7(1)(h)

28 Geoff Hall Sentencing Law and Practice (LexisNexis, Wellington, 2004) at [1.3]

29 Ministry of Justice, above n 17, at [3.6]. 
two alternatives to choose from: the implementation of a single rationale of sentencing; or the implementation of a range of equally weighted rationales. As Professor Andrew Ashworth notes, there is a middle ground whereby the legislature can "declare a primary rationale, and provide that in certain types of case one or another rationale might be given priority". ${ }^{31}$ This is the position in Sweden, and was formerly the position in England under the Criminal Justice Act 1991. ${ }^{32}$

Without a clearly defined hierarchy of sentencing rationales, the current smorgasbord of purposes and principles found under the Sentencing Act are of little practical assistance to sentencing judges.

\section{B Guideline Judgments}

Given the effective failure of the Sentencing Act to guide the application of judicial discretion, commentators such as Ip believe that the sentencing guideline judgments (also known as tariff judgments) issued by the Court of Appeal are a superior means of ensuring discretion is applied consistently in the criminal sentencing context. ${ }^{33}$ This view is echoed by the Law Commission which, despite having some sympathy for the Sentencing Act, conceded that ss 7 and 8 "provide little or no assistance in determining the 'tariff' custody threshold or sentence length appropriate for the average case of each type coming before the courts". 34

Guideline judgments issued by the appellate courts provide authoritative guidance on how to approach sentencing for particular types of offences. These judgments generally set out sentencing "bands" of escalating seriousness depending on the number and nature of aggravating factors relating to the offending. The court gives examples of the types of aggravating features that fall within each band, and sets a range of sentencing starting points for each. ${ }^{35}$ Subsequent judges can then slot the case before them into one of the bands of the appropriate guideline judgment to determine a starting point, before individualising the sentence with a consideration of the relevant factors relating to the offender. Guideline judgments exist for a range of serious offences, including (but not limited to) aggravated robbery, ${ }^{36}$ sexual violation, ${ }^{37}$ grievous bodily harm ${ }^{38}$ and various categories of manslaughter cases. ${ }^{39}$

30 Geoff Hall and Stephen O'Driscoll "The New Sentencing and Parole Acts" (New Zealand Law Society Seminar Paper, 2002) at 17.

31 Andrew Ashworth Sentencing and Criminal Justice (4th ed, Cambridge University Press, Cambridge, 2005) at [3.3.1].

32 At [3.3.1]

33 Ip, above n 20.

34 Law Commission, above n 21, at [32].

35 At [37].

$36 R$ v Mako [2000] 2 NZLR 170 (CA). 
These Court of Appeal decisions have a number of benefits for the application of judicial discretion. They offer the sentencing judge a single source to refer to as a point of reference, saving them from having to consult "the typical scattered and unrelated source[s] of guidance" that exist in the form of precedent. ${ }^{40}$ Indeed, in 2003 the Chief Justice and Chief District Court Judge issued a Practice Note requiring counsel to cite Court of Appeal guideline decisions in their sentencing memoranda where one was available. ${ }^{41}$ Assuming there is a guideline decision on point, "references to other decisions will not be of assistance". ${ }^{42}$ Furthermore, guideline judgments give an indication of how the Court of Appeal might rule should the sentence be appealed, but at the same time leaves the trial judge with sufficient scope to tailor a sentence suitable for the individual circumstances of the case being heard. ${ }^{43}$

Although guideline judgments are intended to achieve consistency, Miller J has noted that they still need to be flexible enough "not to circumscribe the discretion of the sentencing judge". ${ }^{44}$ This is why guideline judgments act only as a starting point. Once the starting point is established, the judge can adjust the sentence depending on the applicable aggravating and mitigating factors of the offender. ${ }^{45}$ Justice O'Regan in $R v$ Taueki went to significant lengths to emphasise this point, highlighting the need to avoid a "rigid or mathematical approach". ${ }^{46}$ Ip characterises this as a judicial fear of the "pendulum swinging from judicial discretion to judicial inflexibility", ${ }^{47}$ but states that guideline judgments strike a balance between consistency and individualised justice. ${ }^{48}$

Despite these advantages, guideline judgments suffer from several major flaws. The first is that such judgments only exist for the most serious offences on the criminal calendar, with the appellate courts providing no guidance on the use of discretion for the mass of less culpable offences dealt

$37 R v A M$ [2010] NZCA 114, [2010] 2 NZLR 750.

$38 \quad R v$ Taueki [2005] 3 NZLR 372 (CA).

39 For example, Кери $v$ R [2011] NZCA 104 discusses single punch manslaughter.

40 Hall, above $\mathrm{n} 28$, at [1.2.2(c)].

41 Sentencing Practice Note 2003 [2003] 2 NZLR 575.

42 At [2.2(h)].

43 Hall, above n 28, at [1.2.2(c)].

$44 R v$ Patea-Glendinning [2006] DCR 505 at [58]; see also $R v$ Mako, above n 36, at [60].

$45 R v$ Mako, above n 36, at [62].

$46 R v$ Taueki, above $\mathrm{n} 38$, at [16].

47 Ip, above n 20, at 399.

48 At 399 . 
with daily in the lower courts. ${ }^{49}$ They almost exclusively deal with offences that warrant a term of imprisonment and as a result, "guidance as to the custody threshold or the use of community-based sentences is very limited". ${ }^{50}$ This is of particular concern given that inconsistency is more likely to occur at those lower levels of offending. It means that the Court of Appeal is unable to "give coherence to sentencing as a whole", ${ }^{51}$ because if the Court wishes to issue a guideline on a particular offence, it must wait until an appropriate case is appealed up through the court hierarchy. There is also a distinct problem in that guideline judgments lack the input and expertise of the District Court judiciary, who are responsible for the vast bulk of sentencing in New Zealand. ${ }^{52}$

Furthermore, the Court of Appeal is inherently ill-placed to undertake the sort of systematic research required to guide meaningful sentencing policy. It does not have the resources or time to undertake substantive empirical research, nor can it investigate the wider impact of sentencing policy in the same way the legislature can. ${ }^{53}$ As Dr Warren Young notes, because sentencing severity levels are determined by the courts without any consideration of financial costs and benefits, punishment becomes the only item on the Government's agenda that is a "free good" - or in other words, it does not have to compete for funding in the same way other elements of the criminal justice system do (for example, policing) ${ }^{54}$ This, according to the Law Commission, is an untenable position. The Commission dismissed the argument that it is improper for fiscal considerations to constrain the imposition of an appropriate punishment, asserting that such a theory assumed that there is in fact a "right" punishment in any given case to start with. ${ }^{55}$ "In reality", the Law Commission says, "punishment levels are a matter of values, and costs are one of the relevant factors informing those values". ${ }^{56}$

Public debate should inform these values - their interpretation should not be left to the whim of the unelected judiciary. This highlights the democratic deficit inherent in guideline judgments. If Parliament wishes to alter sentencing levels, it only has recourse to the blunt tool of amending maximum penalties in the hope that this will have a trickle-down effect on the ordinary run of

49 Hall, above n 28, at [1.2.2(c)].

50 Bruce Robertson (ed) Adams on Criminal Law - Sentencing (online looseleaf ed, Brookers) at [SAC6].

51 Hall, above n 28, at [1.2.2(c)].

52 Law Commission, above n 21, at [39].

53 At [39].

54 Warren Young "Sentencing Reform in New Zealand: A Proposal to Establish a Sentencing Council" in Arie Freiberg and Karen Gelb (eds) Penal Populism, Sentencing Councils and Sentencing Policy (Willan Publishing, Devon, 2008) 179 at 184.

55 Law Commission, above n 21, at [45].

56 At [45]. 
cases. ${ }^{57}$ This is an inherently unusual impediment on Parliament's supremacy to determine such a critical area of what is essentially social policy. Sentencing should (to at least some minimum extent) be determined by Parliament as an elected body representing the people, not by judges "who must of necessity distance themselves from the political and public debate that swirls around that policy". 58

\section{EMPIRICAL EVIDENCE OF DISPARITY IN SENTENCING}

Disparity is inevitable when judges are endowed with discretion. This was acknowledged by the architects of the Sentencing Act, with the Justice and Electoral Committee noting that without clear sentencing guidelines there is an increased risk of judges handing down different sentences for like offenders. ${ }^{59}$ Judges are only human, and will analyse a case consistent with their personal beliefs and experiences. Hall aptly articulates this weakness: ${ }^{60}$

Sentencing is not a rational mechanical process; it is a human process and subject to all the frailties of the human mind. A wide variety of factors, including the Judge's background, experience, social values, moral outlook, penal philosophy and views as to the merits or demerits of a particular penalty influence the sentencing decision.

This has been proven empirically. Writing in 1991, Hall examined a number of studies that highlight sentencing discrepancies. ${ }^{61}$ For example, a report commissioned by the then Department of Justice found that there were significant regional differences in custodial sentences for seven of the eight offence types analysed, which were "most likely caused by differences in the severity of sentencing by judges in different court areas". ${ }^{62}$ This was corroborated by a 1990 study which concluded that "the court at which the charge [is] heard also affects the chance of conviction, the probability of imprisonment, and the length of the prison sentence imposed". ${ }^{3}$ These studies were undertaken before the passage of the principles and purposes of sentencing of the Sentencing Act, and while guideline judgments in New Zealand were still in their infancy.

57 Young, above n 54, at 182.

58 Young, above n 54, at 182.

59 Sentencing and Parole Reform Bill 2001 (17-3) (select committee report) at 1.

60 Hall, above n 28, at [2.1].

61 Geoff Hall "Reducing Disparity by Judicial Self-Regulation: Sentencing Factors and Guideline Judgments" (1991) 14 NZULR 208.

62 P Spier An Examination of Regional Differences in the Use of Custodial Sentences in the District Courts (unpublished report, Policy and Research Division Department of Justice, Wellington 1989) at 49.

63 J Palmer "An Examination of Discretion and Disparity in Judicial Sentencing Behaviour" (LLB(Hons) research paper, University of Otago, 1990). 
However, more recent studies also highlight a disparity in sentencing. Although New Zealandbased literature in this area is sparse, a 2003 study shows that sentencing judges exercise considerable leniency towards women when determining the length of sentences imposed. ${ }^{64}$ The Law Commission itself ordered a report that investigated regional variations in District Court sentencing, ${ }^{65}$ which showed that across the five offence types selected, ${ }^{66}$ some regions were systematically more severe than others. This study was viewed with trepidation by Priestley J, who indicated that some degree of discrepancy was inevitable if you properly left the judiciary discretion to formulate individualised sentences. ${ }^{67}$ Indeed, the Law Commission's study was methodologically limited and unable to control for other factors that may lead to disparity.

In 2013, Wayne Goodall and Russil Durrant published an article that analysed the regional variations in sentencing for the offence of aggravated drink driving in New Zealand. ${ }^{68}$ It was found that "the circuit in which an offender is sentenced for aggravated drink driving significantly affects the likelihood of incarceration", even when controlling for factors such as the seriousness of the offence and criminal history. ${ }^{69}$ They concluded that the existing mechanisms to address sentencing variability were flawed, ${ }^{70}$ and explicitly disproved Priestley J's proposition that individualised sentences inherently required disparity, claiming that unjustified discrepancy still occurred even when controlling for the core sentencing factors that judges need to weigh up in order to achieve individualised justice. ${ }^{71}$ It is interesting to note that Goodall does not think that individual judges should be blamed for this discrepancy. He says that they are simply working within the boundaries of the inadequate system as it currently exists - "they are left in a vacuum and they have no choice but to form their own rules". ${ }^{72}$ This is consistent with the problems identified earlier: the

64 Samantha Jeffries, Garth Fletcher and Greg Newbold "Pathways to Sex-Based Differentiation in Criminal Court Sentencing" (2006) 41 Criminology 329 at 347.

65 Law Commission Regional Analysis of Variations in District Court Sentencing (NZLC MP0, 2006); and Law Commission, above n 21, at appendix.

66 Grievous assault; theft; conversion; breach of community work; and driving under the influence.

67 Justice John Priestley "Chipping Away at the Judicial Arm?" (Harkness Henry Lecture, University of Waikato, October 2009) at 33.

68 Wayne Goodall and Russil Durrant "Regional Variation in Sentencing: The incarceration of aggravated drink drivers in the New Zealand District Courts" (2013) 46 Australian and New Zealand Journal of Criminology 422. See also Wayne Goodall "Sentencing Consistency in the District Courts" (PhD Thesis, Victoria University of Wellington, 2014).

69 At 441 .

70 At 444. Note that this study was limited to aggravated drink driving, and does not necessarily reflect sentencing practice more generally.

71 At 441 .

72 New Zealand Law Society "Stark Difference in Sentencing Identified" LawTalk (online ed, 11 October 2013). 
ineffectiveness of sentencing principles and purposes to guide discretion, and a lack of guideline judgments for low-level offending.

How can New Zealand remedy this grossly unsatisfactory situation? There exists a spectrum along which Parliament can circumscribe judicial discretion at greater or lesser levels. The rest of this article will examine where on that spectrum the legislature should intervene, or to paraphrase Lord Bingham of Cornhill, how short a leash "the dragon of arbitrary discretion" should be given. ${ }^{73}$ At one end of the spectrum lies mandatory sentences, which would circumscribe discretion entirely; at the other, an "intuitive synthesis" approach that gives sentencing judges an almost unfettered ability to impose whatever penalty they see fit to achieve justice in the individual case. The preferred outcome, not surprisingly, can be found somewhere in the middle.

\section{MANDATORY SENTENCES}

The introduction of mandatory sentences would be a simple way for the legislature to achieve consistency in sentencing. Strictly speaking, this involves setting a fixed penalty for the commission of a criminal offence, effectively removing judicial discretion at the sentencing stage entirely. ${ }^{74}$ New Zealand has several incidences of mandatory penalties, including life imprisonment for treason, ${ }^{75}$ and more recently the implementation of the Sentencing and Parole Reform Act 2010. Known colloquially as the "three strikes law", this Act requires a judge to impose the maximum term of imprisonment prescribed for serious violent offending ${ }^{76}$ if the offender is being sentenced for a stage-3 offence (or, in other words, is on their "third strike"). ${ }^{77}$ Variants on the concept of mandatory sentencing can also include the imposition of mandatory minimum sentences, from which the court can then impose a more harsh sanction depending on the severity of the offending. While mandatory sentences have historically enjoyed some popularity, their widespread implementation in New Zealand is neither realistic nor desirable.

\section{A Lack of Individualisation}

The first and most significant flaw of mandatory sentencing is that like offenders will not be treated alike. It is a long established principle of the criminal law that all of the circumstances of the offence and the offender should be taken into account in order for a judge to tailor a sentence that is

73 Lord Bingham "The Discretion of the Judge" (1990) 5 Denning LJ 27 at 28.

74 Declan Roche "Mandatory Sentencing" (1999) 138 Trends and Issues in Crime and Criminal Justice at 1.

75 Crimes Act 1961, s 74(1).

76 Section 86 A of the Sentencing Act 2002 provides an exhaustive list of what qualifies as a "serious violent offence".

77 Sentencing Act 2002, s 86D. 
appropriate in the individual case. ${ }^{78}$ A rigid system that removes judicial discretion through the use of mandatory sentences may technically succeed in its goal of achieving consistency within offence categories themselves, but it would come at the expense of individualised justice.

When the Attorney-General vetted New Zealand's three strikes legislation for compliance with the New Zealand Bill of Rights Act 1990, he noted that the regime "may result in gross disproportionality in sentencing", ${ }^{79}$ and on that basis was inconsistent with the right not to be subject to disproportionately severe treatment or punishment. ${ }^{80}$ This is an inevitable problem of all mandatory sentences. A wide assortment of conduct can fall within any defined offence, ranging from minimally culpable conduct that may result in a discharge, ${ }^{81}$ right through to conduct that is so serious that it warrants a term of imprisonment at or near the maximum prescribed for the offence. Where then should Parliament set the quantum of any mandatory sentence? This is a question of politics.

The shape of a criminal justice system will be dependent on the political and social context within which it has to operate, with sentencing in particular being described by one former Minister of Justice as a "social battleground". 82 As a result, the question of quantum cannot be divorced from an analysis of the influence penal populism has had in New Zealand. Penal populism has resulted in increasingly punitive rhetoric and policies from successive governments, and as identified earlier, one of the highest incarceration rates in the Western world. In 1999 New Zealanders voted overwhelmingly in favour (91.75 per cent) of a Citizens Initiated Referendum instigated by Norm Withers, which asked: "Should there be a reform of our justice system placing greater emphasis on the needs of victims, providing restitution, and compensation for them, and imposing minimum sentences and hard labour for all serious violent offenders?"83 Despite the leading nature of the question and the conflation of several distinct issues, politicians have since used it as a mandate to

78 James Spigelman, Chief Justice of New South Wales "Consistency and Sentencing" (Keynote address to Sentencing 2008 Conference, National Judicial College of Australia, Canberra, 8 February 2008).

79 Christopher Finlayson Report of the Attorney-General under the New Zealand Bill of Rights Act 1990 on the Sentencing and Parole Reform Bill (2009) at [15].

80 New Zealand Bill of Rights Act 1990, s 9.

81 Sentencing Act 2002, s 108.

82 Geoffrey Palmer Reform: A Memoir (Victoria University Press, Wellington, 2013) at 323

83 "Citizens Initiated Referendum (Appointed Day) Order (No. 2) 1999" (29 July 1999) 1999-ps5466 New Zealand Gazette 2073. 
push for longer sentences, ${ }^{84}$ even though the recorded crime rate had in fact been decreasing since 1991, and has continued to decrease through into the 21 st century. ${ }^{85}$

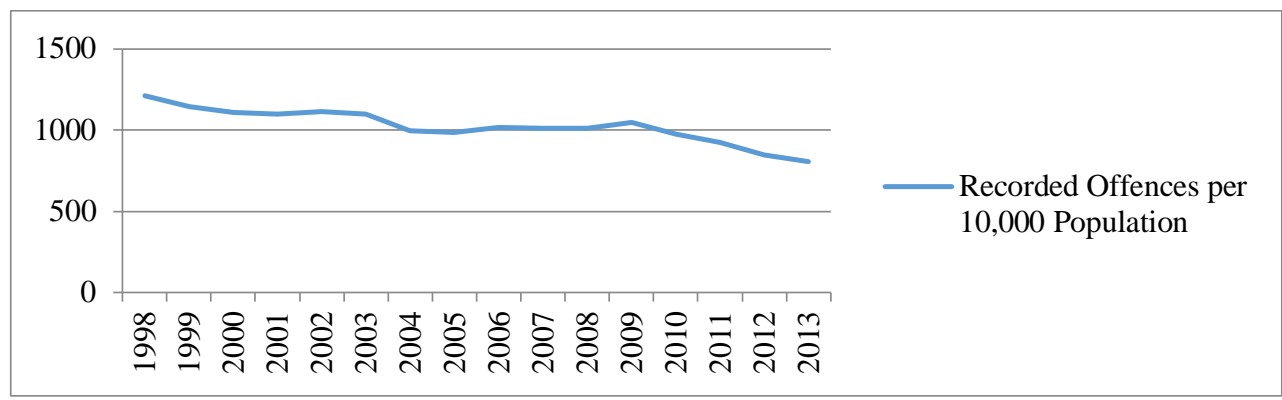

The power and influence wielded by hard-line law and order lobby groups such as the Sensible Sentencing Trust (SST) exacerbates the problem of penal populism. Pratt describes politicians as "running to catch up with [the SST's] demands", ${ }^{86}$ and in 2010, Prime Minister John Key gave a speech at the SST conference praising the organisation as "courageous advocates for victims of crime" who play a "vital role in ... promoting a safer New Zealand". ${ }^{87}$ Such dialogue is a blatant attempt by politicians to demonstrate their law and order credentials, and to foster a reputation for being "tough on crime". It results in a situation whereby political parties attempt to outbid each other with increasingly punitive policies, ${ }^{88}$ in order to appease a public who grossly overestimates the level of offending in society. ${ }^{89}$ Furthermore, the mixed member proportional (MMP) electoral system gives significant influence to smaller "fringe" parties, who are able to push through their law and order policies in exchange for giving larger political parties the numbers to govern. ${ }^{90}$ All these factors contribute towards a political culture that would almost certainly lead the Government to take a hard-line approach when determining the quantum of mandatory sentences. Individualised justice would be usurped by punitive uniformity.

84 John Pratt and Maria Clarke "Penal populism in New Zealand" (2005) 7 Punishm Soc 303 at 306.

85 New Zealand Police "Crime Statistics for calendar year ending 31 December [2000-2013]" <www.police.govt.nz>.

86 Pratt and Clarke, above n 84 , at 306.

87 John Key, Prime Minister of New Zealand "Speech to Sensible Sentencing Trust Conference" (Parliament Buildings, Wellington, 25 August 2010).

88 Palmer, above n 82, at 613.

89 See Judy Paulin, Wendy Searle and Trish Knaggs Attitudes to Crime and Punishment: A New Zealand Study (prepared for the Ministry of Justice, 2003).

90 John Pratt "Penal Scandal in New Zealand" in Arie Freiberg and Karen Gelb (eds) Penal Populism, Sentencing Councils and Sentencing Policy (Willan Publishing, Devon, 2008) 31 at 38. 


\section{B Reassignment of Discretion to Prosecutors}

The implementation of mandatory sentences would not eliminate discretion, it would merely give it to other actors in the criminal justice system, particularly to police and Crown prosecutors. By removing the discretion judges enjoy, these agencies would in effect get to decide who goes to prison and for what length of time, contingent on what charges they decided to lay. ${ }^{91}$

Placing sentencing discretion in the hands of prosecutors causes a number of problems. A prosecutor, when deciding what charge is suitable, is not in a position to take into account all the relevant circumstances of the offence and the offender in the same way a judge can after the benefit of a sentencing hearing. When deciding what charge to lay the prosecutor must take into account factors such as the sufficiency of evidence, and this is a very distinct exercise from balancing the factors that make up an appropriate sentence. Furthermore, the decision to lay a particular charge takes place behind closed doors and lacks transparency. In contrast, the sentencing decisions of judges are publically available $\mathrm{e}^{92}$ and there is a legislative requirement that judges provide reasons for the sentence they have imposed. ${ }^{93}$ This in turn allows a defendant to appeal their sentence, an important safeguard that is enshrined in the Bill of Rights Act, ${ }^{94}$ whereas a defendant is unable to appeal the prosecutor's choice of charge laid.

There is also clear evidence that prosecutors will soften their approach in light of mandatory sentences in order to mitigate against unduly harsh outcomes. In the United States, in the context of mandatory minimum sentences, studies have shown that prosecutors are often reluctant to prosecute some offences due to the penalty being disproportionate to the gravity of the offending. ${ }^{95}$ Due to the inflexibility of mandatory sentences, they will instead file charges for different, but roughly comparable, offences that are not subject to the mandatory sentencing regime. ${ }^{96}$ As a result, inconsistency will shift from the quantum of the sentence to what charge is laid in the first place. Distortions in prosecutorial practice would be a real issue in New Zealand, as the Prosecution Guidelines issued by the Solicitor-General only require a prosecutor to ensure that the "charges filed ... adequately reflect the criminality of the defendant's conduct". ${ }^{97}$ This very broad and subjective

91 Rob White "10 arguments against mandatory sentencing" (2000) 19 Youth Studies Australia 22 at 23.

92 Roche, above n 74, at 5.

93 Sentencing Act 2002, s 31.

94 New Zealand Bill of Rights Act 1990, s 25(h).

95 David Bjerk "Making the Crime Fit the Penalty: The Role of Prosecutorial Discretion under Mandatory Minimum Sentencing" (2005) 48 Journal of Law and Economics 591 at 594.

96 Michael Tonry Sentencing Matters (Oxford University Press, New York, 1996) at 147.

97 Crown Law Office Solicitor-General's Prosecution Guidelines as at 1 July 2013 (Crown Law Office, June 2013) at [8.1] 
discretion provides plenty of scope for prosecutors to engage in the same attempts at mitigation as their American counterparts.

\section{Statutory Presumptions}

It is clear that the widespread implementation of mandatory sentences would be detrimental to the criminal justice system. The pursuit of consistency would come at the expense of fairness and proportionality, and would merely give greater discretion to prosecutors. However, another option would be for the legislature to create statutory presumptions as to what a sentence should be, with the ability of a judge to rebut that presumption and impose a shorter sentence if necessary.

Such an approach currently exists for the offence of murder, where there is a legal presumption requiring a court to impose a sentence of life imprisonment unless, given the circumstances of the offence and the offender, such a sentence would be "manifestly unjust". ${ }^{98}$ During the first reading of the Bill, the Minister of Justice said that the inclusion of a rebuttable presumption in s 102 would reduce the likelihood that a jury, in order to compensate for a lack of flexibility at sentencing, ${ }^{99}$ would return a verdict of manslaughter rather than murder. ${ }^{100}$ Once the court considers it manifestly unjust to impose a life sentence and accordingly rebuts the presumption, the full range of sentencing options under the Sentencing Act become available. ${ }^{101}$ The court will therefore have recourse to any sentence it thinks appropriate to fulfil the principles and purposes of sentencing.

Rebuttable statutory presumptions would go some ways to achieving consistency in sentencing, whilst leaving judges with sufficient residual discretion to impose a lesser sentence when necessary. The key would be establishing a fair threshold at which the presumption can be displaced. In relation to murder, the threshold of manifest injustice is incredibly high, with Elias CJ indicating that it "is a conclusion likely to be reached in exceptional cases only". ${ }^{102}$ Distinctions around culpability must instead be made when determining what minimum non-parole period to impose. This approach does not therefore remedy the underlying problem: impose a high threshold before a judge is authorised to depart from the presumption and the sentences imposed will not be able to reflect the varying culpability levels; impose a low threshold before departure and the same problems around discretion and inconsistency apply.

98 Sentencing Act 2002, s 102. The sentencing regime is different if the murder is a stage-2 or stage-3 offence under s 86E of the Sentencing Act 2002.

99 The Criminal Justice Act 1985 made life imprisonment for murder mandatory. The sentencing judge had no discretion to impose a lesser sentence.

100 (14 August 2001) 594 NZPD 10910-10911.

$101 R v \operatorname{Law}(2002) 19 \mathrm{CRNZ} 500(\mathrm{HC})$ at [52].

$102 R$ v Rapira [2003] 3 NZLR 794 (CA) at [121]. 


\section{VI "INSTINCTIVE SYNTHESIS" - AN INDIVIDUALISED APPROACH TO SENTENCING}

If mandatory sentences sit at one extreme of any spectrum on how to guide judicial discretion, then the instinctive synthesis approach surely sits at the other. During the 20th century, senior judges around the British Commonwealth began to adopt the view that sentencing was not an area that could be regulated by Parliament with mathematical precision or formulae, and that "all ... well-experienced judges could do was to agree on a range of sentences that could respectably be said to fit all the circumstances of the case". ${ }^{103}$ On this line of thinking, particular rules and mechanisms as to how judges should exercise their discretion are unnecessary and unhelpful, because there is no inherently "right" sentence to impose. Indeed, Jordan CJ mused that "the only golden rule is that there is no golden rule". ${ }^{104}$

This liberal and individualist style of sentencing has found extensive support from the senior judiciary in both Australia and Canada. The Victorian Supreme Court in $R v$ Williscroft first coined the notion of an "instinctive synthesis" approach to sentencing in $1975,{ }^{105}$ a concept which has been cited and refined multiple times since, ${ }^{106}$ and which now refers to an exercise whereby "all relevant considerations are simultaneously unified, balanced and weighed by the sentencing judge". ${ }^{107}$ To this end, a judge does not need to explicitly lay out the reasons behind the sentence he or she arrives at, because all that matters is the sentence itself. ${ }^{108}$ It is the intuitive weight that a sentencing judge decides to place on the circumstances of the offence and the offender after the benefit of hearing all the evidence which is important - not the process of jumping through formulaic hoops set by the legislature. The method can therefore be sharply distinguished from the current tiered approach found in New Zealand which involves establishing an appropriate starting point that is then adjusted for personal aggravating and mitigating factors. As a result, the instinctive synthesis approach to sentencing has been characterised as "more art than science". ${ }^{109}$

However, other judges and commentators have viewed this approach with a degree of consternation, noting a number of significant flaws. Kirby $\mathbf{J}$ of the Australian High Court felt that

103 Grant Hammond "Sentencing: Intuitive Synthesis or Structured Discretion?" [2007] NZ Law Review 211 at 213.

$104 R v$ Geddes (1936) 36 SR (NSW) 554

$105 R v$ Williscroft [1975] VR 292 at 300.

106 See $R$ v Markarian (2005) 228 CLR 357; Hili v R (2010) 242 CLR 520; R v Morton [1986] VR 863.

107 Sarah Krasnostein and Arie Freiberg "Pursuing Consistency in an Individualist Sentencing Framework: If You Know Where You're Going, How Do You Know When You've Got There?" (2013) 76 Law and Contemp Probs 265 at 268.

108 Hammond, above n 103, at 214.

109 Krasnostein and Freiberg, above n 107, at 269. 
the approach lacked transparency and was a "retrograde step", ${ }^{110}$ because disclosure around how a particular sentence has been formulated and the reasons for that sentence should not be hidden by judicial reference to instinct or intuition, "which does little to provide any useful insight or engender public confidence in the task of sentencing". ${ }^{111}$ Kirby $\mathrm{J}$ took particular issue with the instinctive synthesis approach in the context of legislatively mandated discounts for guilty pleas, saying that without explicit judicial reasoning it is not possible to know whether the statutory discount provisions have been applied at all, and it becomes impossible for appellate courts to check the sentence for consistency with like cases. ${ }^{112}$ Indeed, consistency itself is not of primary importance under the instinctive synthesis approach. In Wong $v R$, Gleeson CJ noted that although criminal sentencing should not be seen as a "multiplicity of unconnected single instances", a certain level of inconsistency is acceptable and inevitable. ${ }^{113}$ Because the approach eschews the use of any mechanisms that may guide discretion, Krasnostein and Freiberg go as far as to say the approach conceals and normalises disparity. They conclude that because judges do not need to explicitly set out the weight they give to certain factors when formulating their "intuitive" decision, it becomes virtually impossible to assess whether like offenders are routinely treated in the same way. This in turn means that "sentences can be inconsistent within a (potentially vast) margin of error yet [remain] legal". 114

A further problem around the instinctive synthesis approach is the underlying need for a clear rationale of sentencing. Ashworth says that: ${ }^{115}$

It is one thing to agree that judges should be left with discretion, so they may adjust the sentence to fit the particular combination of facts in the individual case. It is quite another to suggest that judges should be free to choose what rationale of sentencing to adopt in particular cases or types of case. Freedom to select from among the various rationales is a freedom to determine policy, not a freedom to respond to unusual combinations of facts.

According to Ashworth, one of the major reasons for sentencing disparity are the different penal philosophies amongst judges and magistrates. ${ }^{116}$ This problem would be magnified exponentially in

110 Wong $v R$ (2001) 207 CLR 584 at [102] per Kirby J dissenting.

111 Sally Traynor and Ivan Potas "Sentencing Methodology: Two-tiered or Instinctive Synthesis?" (2002) Sentencing Trends and Issues 25 at [4.2].

112 Cameron v R (2002) 209 CLR 339 at [70].

113 Wong $v R$, above $\mathrm{n} 110$, at [6].

114 Krasnostein and Freiberg, above n 107, at 269.

115 Andrew Ashworth Sentencing and Criminal Justice (4th ed, Cambridge University Press, Cambridge, 2005) at [3.3.1].

116 At [3.3.1]. 
a situation whereby sentencing judges had unlimited discretion to impose a sentence according to their subjective intuition. Intuitions will invariably differ, and can be plagued by bias, ignorance and prejudice. ${ }^{117}$ A single, clearly defined sentencing rationale - such as rehabilitation or retribution would ensure that judges are exercising their discretion in the pursuit of a common goal. However, in New Zealand (as in other jurisdictions) the Sentencing Act does not set out any single rationale of sentencing. It instead lists eight, equally weighted purposes of sentencing. ${ }^{118}$ As was identified earlier in the article, this is an unsatisfactory mechanism for guiding judicial discretion, because sentencing judges are free to choose whatever purpose they like to justify their imposed penalty depending on their pre-existing penal preferences. Hammond $\mathbf{J}$ has said that: ${ }^{119}$

Before a judge can impose an appropriate sentence, that judge must be properly apprised of the purpose

or purposes to which sentence is directed. And there should be some directions as to how to achieve that

purpose. In the absence of a body of case law, or such legislation, gross disparities in sentence are

inevitable.

If New Zealand were to adopt the intuitive synthesis approach as a means of achieving consistency, it would therefore need to amend s 7 of the Sentencing Act by making it clear what the primary or overriding purpose of sentencing is.

There is nothing in the empowering legislation of New Zealand's sentencing regime that restricts the adoption of the intuitive synthesis approach, ${ }^{120}$ subject to the repeal of certain mandatory provisions of the Sentencing Act. That said, the country lacks the appetite for such a method. New Zealand has to date followed the regulated approach of England, which is in sharp contrast to the individualised style found in parts of Australia and Canada. There would need to be some major catalyst - possibly in the form of public discontent with the status quo - to overhaul the system in such a drastic fashion. However, public sentiment in the field of sentencing generally yearns for the twin aims of greater consistency and harsher sentences - both of which are brought about by less judicial discretion, not more. ${ }^{121}$ This in turn will hamper the political appetite to deregulate the sentencing sphere in the same way Australia and Canada have.

The intuitive synthesis approach would lead to greater disparity in sentencing, make it more difficult for defendants to appeal their sentence, and would require the legislature to undertake the difficult task of settling on a clear purpose of sentencing. Furthermore, there is no discernible appetite for its implementation in New Zealand. While it would undoubtedly be popular amongst

117 Mirko Bargaric "Sentencing: The Road to Nowhere" (1999) 21 Syd L Rev 597 at 609.

118 Sentencing Act 2002, s 7(1).

119 Hammond, above n 103, at 226.

120 At 220.

121 For example the "three strikes" legislation. 
those judges who view their sentencing discretion as sacrosanct, its only real benefit lies in its ability to give judges a wide ability to impose whatever sentence is necessary to achieve justice in a particular case. This, however, can be done without removing guidance in the field of sentencing entirely. The implementation of a Sentencing Council is an effective compromise between the extremes of the instinctive synthesis approach and mandatory sentences, achieving an equilibrium which harnesses the benefits of both.

\section{THE NEW ZEALAND SENTENCING COUNCIL}

In February 2006, the Law Commission was asked by the Labour-led Government to examine the existing parole and sentencing structures in New Zealand. There were two major catalysts behind this project: the disparity of outcome between like offenders due to the highly discretionary nature of New Zealand's sentencing and parole arrangements; ${ }^{122}$ and the immense public dissatisfaction with the lack of "truth in sentencing", or in other words, the perception that the system was unduly lenient because offenders were only serving a fraction of their sentence before being released on parole. ${ }^{123}$ This latter point was an issue of particular political sensitivity, especially given the political traction and media attention being enjoyed by the SST at this time. ${ }^{124}$ The significant difference between the head sentence imposed and the actual time served created a situation that the President of the Law Commission, Sir Geoffrey Palmer, said bordered on deception. ${ }^{125}$

On 11 August 2006, the Commission presented their findings to the Government, recommending (amongst other things) the establishment of a Sentencing Council with a mandate to draft sentencing guidelines. ${ }^{126}$ On 25 July 2007 , by a majority of 70 to 51 , the Sentencing Council Bill was read a third time in Parliament. ${ }^{127}$ It received royal assent within the week, ${ }^{128}$ with a date for the Council's implementation in practice to be determined by Order in Council. ${ }^{129}$ To date, the Government has declined to establish the Sentencing Council, and has indicated that it will not be

122 Law Commission, above n 21, at [5]

123 At [8].

124 See "Trust calls tougher parole plan 'a con"' The New Zealand Herald (online ed, April 26, 2006).

125 "Law Commission looks at doubling parole threshold" The New Zealand Herald (online ed, April 25, 2006).

126 Law Commission, above n 21, at 13.

127 (24 July 2007) 640 NZPD 10652.

128 Sentencing Council Act 2007.

129 Section 2. 
doing so in the future. ${ }^{130}$ For now, the Sentencing Council Act 2007 sits impotent on the statute books.

The Law Commission's report and its recommendations involved intertwined amendments to both the sentencing and parole system. In many respects, it was the changes to parole that were of the most practical importance to the Government and interest to the public. These changes required an offender to serve two-thirds of their nominal sentence before becoming eligible for parole, up from what was universal parole eligibility after just one-third served. ${ }^{131}$ The recommendations would also require the judge to make it clear in open court how much of a sentence would need to be served before the offender became eligible for parole. ${ }^{132}$ That said, this article is interested in how the recommendations will affect consistency in sentencing, and as a result, the focus will be predominantly on the Sentencing Council and the guidelines it can issue.

\section{A Sentencing Guidelines}

The Sentencing Council has a mandate to draft sentencing guidelines, the purposes of which have been enshrined under s 8 of the Sentencing Council Act 2007 and include the need to promote consistency in sentencing practice between different courts and judges. Indeed, consistency was a prominent concern of the Law Commission when constructing its report, noting from the outset the need to ensure "that there is, at a minimum, a consistent judicial approach and a predictable pattern in sentence severity". ${ }^{133}$

In order to achieve consistency the Sentencing Council would issue either narrative or numerical guidelines for judges to follow. Numerical guidelines would set out the nature and range of applicable penalties for an offence, indicating for example a range of appropriate fines or prison term length based on the severity of the offending. This is similar to the function of tariff judgments, which often set out sentencing bands that propose numeric starting points for judges to begin their sentencing analysis. ${ }^{134}$ While numerical guidelines have the benefit of simplicity, both for the comprehension of sentencing judges and the wider public, the Council would need to be careful to ensure that they do not become overly rigid, in turn restricting judges' ability to achieve justice in a particular case. This is what has occurred in the United States. The Federal Sentencing Guidelines implement a numeric, two-dimensional grid through which a judge must calculate the appropriate sentence, with each axis of the grid having regard to offence seriousness and criminal history. This

130 Parliamentary Counsel Office "PCO table of legislation waiting to be brought into force by Order in Council (as at 1 July 2014)" <www.pco.parliamenet.govt.nz>.

131 Law Commission, above n 21, at [178].

132 At [175].

133 At [74].

134 See $R v$ Taueki, above n 38, at [34]. 
approach has been criticised at length by academics, lawyers and judges alike, all of whom argue that the system is fundamentally unable to take into account the complex array of factors that make up sentencing. ${ }^{135}$

To ameliorate the risk of numerical guidelines becoming unduly restrictive, the New Zealand Sentencing Council would also be able to issue conjunctive narrative guidelines. Narrative guidelines offer a textual commentary, and in many respects would be an embellishment of the statutory commentary that already exists under the purposes and principles of the Sentencing Act. ${ }^{136}$ This sort of contextualisation has been considered essential in overseas jurisdictions, and is the approach that has been taken in the United Kingdom. ${ }^{137}$ At the lower end of the spectrum, these guidelines are likely to focus on and discuss the factors that are relevant to the custody threshold. ${ }^{138}$

Any guidelines issued by the Council would have to work within the existing legislative framework. ${ }^{139}$ This means that the Council would have to adhere to the maximum penalties found in legislation, as well as the existing provisions of the Sentencing Act 2002, such as the purposes and principles of sentencing. It is not the role of the Council to recommend changes to maximum penalties, although theoretically it could tender advice to the Minister on such matters under s 25 of the Sentencing Council Act. Such advice would need to fall under the legislatively prescribed ambit of advice "on any sentencing or parole issue that relates to the development and use of sentencing guidelines". ${ }^{140}$

\section{$B$ Implementation of the Guidelines}

The Sentencing Council Act sets out a unique method of giving parliamentary endorsement to the recommended guidelines. ${ }^{141}$ Once the Minister of Justice has been presented with the guidelines (as well as the statement of their likely effect on the prison population), he or she must table them in Parliament. ${ }^{142}$ They will then be referred to the appropriate select committee (almost certain to be the Law and Order Committee), who have 15 days to table a report. ${ }^{143}$ From there, if Parliament

135 See Jed Rakoff "Why the Federal Sentencing Guidelines Should be Scrapped" (2013) 26 Fed Sentencing Rep 6.

136 Law Commission, above n 21, at [96].

137 Law Commission Reforms to the Sentencing and Parole Structure: Consultation Draft (Wellington, April 2006) (Obtained under Official Information Act 1982 Request to the Law Commission).

138 Law Commission, above n 21, at [96].

139 Sentencing Council Act 2007, s 9(1)(a).

140 Section 25.

141 Although the process is broadly similar to the provisions found under s 109 of the Crown Entities Act 2004.

142 Sentencing Council Act 2007, s 17.

143 Law Commission, above n 21, at [113]. 
determines that the guidelines should not come into force, it has 15 days to disallow them by way of a negative resolution on a notice of motion. ${ }^{144}$ If this is not done then the guidelines would come into force 20 working days after the expiry of the specified disallowance period. ${ }^{145}$ If the guidelines are disallowed, they must be sent back to the Council for reconsideration.

This negative resolution procedure ensures appropriate parliamentary involvement in the imposition of guidelines, a mark of democracy that the Law Commission felt was important to ensure the guidelines' legitimacy. ${ }^{146}$ To this end the President of the Law Commission sought input from David McGee QC, the Clerk of the House of Representatives. ${ }^{147}$ McGee broadly agreed with the Commission's proposed negative resolution procedure, but suggested some minor changes. ${ }^{148}$ His advice was adopted by the Committee, and distinct changes have been made between the Criminal Justice Reform Bill and the eventual Sentencing Council Act.

In the original Bill there was a statutory direction requiring the Sentencing Council to vary guidelines that were disallowed by Parliament, as opposed to the Council simply going back and reconsidering them. ${ }^{149}$ Although there were no submissions on this point, the Law Commission later felt that the Council ought to retain the prerogative to refuse to alter its guidelines. This would likely only occur in rare circumstances, but it is important in maintaining the independent status of the Council, especially in light of its extensive judicial involvement. ${ }^{150}$ Similarly, Parliament does not have the power to amend the guidelines that are tabled before it. To do so would be to assume the role of the expert body it has already set up. If Parliament is dissatisfied with the guidelines, "the

144 Sentencing Council Act 2007, s 19.

145 Section 21.

146 Law Commission, above n 21, at [112].

147 Letter from Sir Geoffrey Palmer (President of the Law Commission) to David McGee (Clerk of the House) regarding the Criminal Justice Reform Bill (5 April 2006) (Obtained under Official Information Act 1982 Request to the Law Commission).

148 Letter from David McGee (Clerk of the House) to the Justice and Electoral Committee regarding the Criminal Justice Reform Bill (15 May 2007) (Obtained under Official Information Act 1982 Request to the Law Commission). For example, it was originally suggested that the Leader of the House would move a motion referring the guidelines to an appropriate select committee for consideration, but McGee felt that this was unnecessary and that the Standing Orders could provide for the guidelines to automatically stand referred to a committee. In a submission to the Justice and Electoral Select Committee, McGee also expressed concern that the Criminal Justice Reform Bill explicitly set out the nature of the negative resolution process, even though it is an internal parliamentary process that does not need to be legislated for.

149 Criminal Justice Reform Bill (93-1), cl 24.

150 Law Commission "Criminal Justice Reform Bill: Law Commission Departmental Report" (presented to the Justice and Electoral Select Committee, 9 May 2007) (Obtained under Official Information Act 1982 Request to the Law Commission) at [148]. 
negative resolution procedure allows it to express this by rejection, but not by becoming the Sentencing Council itself". 151

\section{The Council's Role in Managing Penal Resources}

Consistency was not the only purpose of introducing sentencing guidelines. Under s 8(a)(iv), the guidelines must also "facilitate the provision of reliable information to enable penal resources to be effectively managed", and the broader functions of the Council are to "assess and take account of the overall costs and benefits of the guidelines", ${ }^{152}$ as well as provide a statement on the guidelines' likely effect on the prison population. ${ }^{153}$ As discussed earlier, one of the major flaws with the current sentencing system is that the Court of Appeal is ill-equipped to undertake the comprehensive empirical research necessary to guide sentencing policy. The Court issues guideline judgments, but it is unable to weigh up the relative costs and benefits of its recommended sentencing levels and their corresponding impact on the prison population. Punishment, in effect, becomes a "free" good.

The use of the sentencing guidelines would entirely rectify this situation. Because the Sentencing Council would be required to undertake prison population modelling to assess the effect of its recommendations, the executive would in turn attain a significantly enhanced control of its Corrections budget. ${ }^{154}$ For the first time the Government (as opposed to the Court of Appeal) would be able to determine where sentencing levels should be set, giving it the opportunity to implement only those guidelines that are consistent with its broader aims in the law and order sector and with reference to budgetary constraints. Not only would this result in better-informed policy, but the greater influence of Parliament also ensures that sentencing levels are democratically legitimate. It is worth noting too that in the United Kingdom, resource considerations and cost-effectiveness are not explicitly taken into account by the Sentencing Council. However, the Lord Chief Justice and the President of the Queen's Bench Division have both indicated that the system "would be improved if resource consideration were a more explicit part of the process". 155

Some of the submissions on the Criminal Justice Reform Bill were concerned that the Council itself had a vested interest in reducing the imprisonment rate in New Zealand. This was in part due to the Bill's explanatory note, which asserted that the purpose of the legislation was to "arrest the sharp increase in prison population" and "contribute to a reduction in the imprisonment rate over

151 McGee, above n 148.

152 Sentencing Council Act 2007, s 9(1)(c).

153 Section $9(1)(d)$.

154 Law Commission, above n 21, at [74].

155 Sentencing Guidelines Establishment Unit Report on visit to English Sentencing Council, 6 - 17 November 2006 (Wellington, 2006) at [19]. 
time". ${ }^{156}$ One submission reasoned that such an intention is inappropriate because there is the possibility that the Council would issue guidelines that increase sentence levels, depending upon the composition and inclination of its members. ${ }^{157}$ This is entirely correct. The Law Commission later accepted that the explanatory note was "over-generalised", ${ }^{158}$ and that in reality the Council's role is more nuanced. Although overseas literature indicates that "when legislatures are required to make law and order choices in light of their predictable fiscal effects, prison population expansion tends to be curbed or muted", in practice the Council is able to produce guidelines that would maintain or even increase the number of people incarcerated. ${ }^{159}$

\section{Composition of the Council}

The Council would be comprised of 10 members: one Judge of the Court of Appeal; one Judge of the High Court; two District Court Judges; the chairperson of the Parole Board; ${ }^{160}$ and five lay members. ${ }^{161}$ The Sentencing Council in the United Kingdom has 12 members, but the Director of Public Prosecutions has said that this is too big and is difficult to manage. ${ }^{162}$ According to the Law Commission, 10 is the optimum number to guarantee the Council is representative, but also small enough to ensure that it is cohesive, efficient and publicly credible. ${ }^{163}$

Whether there needed to be a judicial majority on the Council was a key issue, and overseas commentators were divided as to the appropriate ratio for such bodies. For example, Michael Tonry believed that senior English judges would not cooperate with any issued guidelines unless the judiciary had control over the Council, but the United States experience showed that a purely judicial body would not create guidelines with "sufficient rigour" to achieve consistency. ${ }^{164}$ Consultation with the New Zealand judiciary indicated that a judicial majority would be unnecessary, due in part to the significant policy function of the Council, but that its membership

156 Criminal Justice Reform Bill 2007 (93-1), explanatory note.

157 Michael Bott "Submission to the Justice and Electoral Select Committee on the Criminal Justice Reform Bill".

158 Law Commission, above n 150, at [49].

159 At $[51]$.

160 The chairperson of the Parole Board gets a seat because of the Council's function of also drafting parole guidelines, see s 9(1)(b). This aspect of the Sentencing Council's jurisdiction falls outside the ambit of this article.

161 Sentencing Council Act 2007, s 10.

162 Sentencing Guidelines Establishment Unit, above n 156, at [9].

163 Law Commission, above n 21, at [81].

164 Michael Tonry "Setting sentencing policy through guidelines" in Sue Rex and Michael Tonry Reform and Punishment: The Future of Sentencing (Willan Publishing, New York, 2002) 75 at 80. 
needed to ensure that the guidelines are "tailored to the range of circumstances that confront sentencing judges on a daily basis". ${ }^{165}$ It was decided that four judges plus the chairperson of the Parole Board, who by statute is also a judge, ${ }^{166}$ would ensure that the Council can fully appreciate the realities of sentencing in practice, and would instil wider judicial confidence in the system. ${ }^{167}$

The input of District Court judges in particular allows the Council to draw on experience from those at the forefront of sentencing in New Zealand, rectifying one of the major problems associated with tariff judgments as a means of guiding judicial discretion. It is interesting to note that there is no restriction on the lower court judge from taking on the role of chairperson, effectively placing him or her in a more senior position on the Council to their superior court colleagues. ${ }^{168}$ However, the chairperson would be appointed by the Chief Justice, who has already indicated her preference that a senior judge take the role. ${ }^{169}$ The Criminal Justice Reform Bill originally required the chairperson to be one of the non-judicial members, but this was amended by the Justice and Electoral Select Committee after consultation with the judiciary, stating that "the appointment of a judicial chairperson would encourage judicial confidence in the Council, and would also be more likely to help the Council achieve one of its core purposes, consistency in sentencing". ${ }^{170}$

The judicial members would be appointed by their respective Head of Bench in consultation with the Chief Justice, ${ }^{171}$ presumably based on expertise or interest in the area. ${ }^{172}$ The remaining members would be appointed by the Governor-General on the recommendation of Parliament, ${ }^{173}$ with the Minister of Justice emphasising that their selection "is not an area where partisan considerations have any place". ${ }^{174}$ Whether partisan preferences can be avoided in a political system blighted by penal populism is uncertain, with the Law Society expressing concern that the

165 Law Commission, above n 21, at [83].

166 Parole Act 2002, s 112.

167 Warren Young and Andrea King "Sentencing Practice and Guidance in New Zealand" (2010) 22 Fed Sentencing Rep 254 at 258.

168 The role of chairperson is appointed by the Chief Justice, and is restricted to one of the judicial members of the Council, see s 10(2).

169 Letter from Dame Sian Elias (Chief Justice) to Lynne Pillay (Chairperson of the Justice and Electoral Select Committee) regarding the Criminal Justice Reform Bill (24 April 2007) (Obtained under Official Information Act 1982 Request to the Law Commission) at [7].

170 Criminal Justice Reform Bill (93-2) (select committee report) at 2.

171 Sentencing Council Act 2007, s 10(1).

172 Law Commission, above n 21, at [90].

173 Sentencing Council Act 2007, s 10(1)(e).

174 (24 July 2007) 640 NZPD 10633. 
"membership of the Council could become politically contentious". ${ }^{175}$ However, sch 1(1) of the Act sets out the criteria Parliament should consider when recommending an appointment. This includes experience in: criminal justice matters, policing, the assessment of risk of reoffending, the effect of the criminal justice system on Māori and minority cultures, the promotion of the rights and welfare of victims of crime, and public policy. ${ }^{176}$ In the original version of the Bill these were mandatory considerations that had to be taken into account by Parliament, but this was changed after the Select Committee felt it was too prescriptive and inhibited the ability of the House to regulate its own procedures. ${ }^{177}$

During submissions on the Bill, various interest groups claimed that they should have mandatory representation on the Council. For example, the Royal Federation of New Zealand Justices' Association argued that they should have a representative due to the "heavy involvement of Justices of the Peace ... at the lower end of the Court structure". ${ }^{178}$ However, if the Council is to remain at a workable size it is simply impractical to ensure that every interested party in the criminal justice system has a say. Appointments based on expertise in the area is flexible enough to ensure that a broad cross-section of lay people can contribute to the guidelines. Assuming that expressions of interest are widely publicised using a range of media, the system as it stands would also ensure that there is healthy competition to fill the vacant positions, in turn increasing the calibre of expertise on the Council. This was aptly articulated by the Law Commission, who said that "the quality of appointees to the Council and the resulting community confidence in them is a more important consideration than a desire for 'representativeness"'. ${ }^{179}$ In any event, the Council is required to undertake extensive public consultation anyway, ${ }^{180}$ which is an appropriate mechanism to ensure that all interested parties have their views heard.

Members would hold office for a term of five years, ${ }^{181}$ which can be extended to a term not exceeding seven years. ${ }^{182}$ If necessary, members of the Council can be removed or suspended. For

175 New Zealand Law Society "Submission to the Justice and Electoral Select Committee on the Criminal Justice Reform Bill" at [4(e)].

176 It is interesting to note that expertise in sentencing is not on this list. It was thought that the expertise of the judicial members of the Council would be sufficient in this respect. However, this may preclude experienced academics who have specialised knowledge of criminal sentencing from becoming members.

177 Criminal Justice Reform Bill (93-2) (select committee report) at 3.

178 Royal Federation of NZ Justices Association "Submission to the Justice and Electoral Select Committee on the Criminal Justice Reform Bill" at 3.

179 Law Commission, above n 150, at [89].

180 Sentencing Council Act 2007, s 13.

181 Not including the chairperson of the Parole Board.

182 Sentencing Council Act 2007, sch 1, cl 3. 
the judicial members this is done via the same process that is required to remove them from office as a Judge. ${ }^{183}$ The lay members can be removed or suspended by the Governor-General "on address from the House of Representatives, for inability to perform the functions of office, neglect of duty, or misconduct". ${ }^{184}$

\section{E Departure from the Guidelines}

Although the guidelines would exist to achieve greater consistency in sentencing across New Zealand, there will always be a risk that a judge may need to depart from the guidelines to achieve justice in a particular case. The Law Commission acknowledged this, stating that "the threshold beyond which judges passing sentence in individual cases would be permitted to depart from sentencing guidelines is clearly integral to their success". ${ }^{185}$

The Law Commission recommended a public interest test for departure, which would require a sentencing judge to "impose a sentence that is consistent with any sentencing guidelines that are relevant in the offender's case, unless the court is satisfied that it would be contrary to the interests of justice to do so". ${ }^{186}$ This test is now included in s 12 of the Sentencing Amendment Act 2007, but has not yet been brought into force through Order in Council. A judge would need to justify their reasons for departing from a guideline, ${ }^{187}$ but it was forecast that departures would occur in no more than 20 per cent of cases. ${ }^{188}$

The Justice and Electoral Committee did not immediately adopt the Commission's recommendation, finding virtue instead in the United Kingdom's formulation of the departure test. This merely requires the court to "have regard to any guidelines which are relevant to the offender's case", ${ }^{189}$ which is a much looser form of control over discretion. The Acting Chief Justice gave oral evidence to the Committee on this point, noting that judges (perhaps surprisingly) preferred the Commission's more stringent approach. This view was echoed by the Chief High Court Judge, but who added that so long as the guidelines were flexibly drafted, either formulation would be acceptable. The Law Commission was less ambivalent, arguing that "a guideline that is purely advisory may not carry sufficient weight to effect a substantial change", particularly given the levels

183 Schedule 1, cl 6.

184 Schedule $1, \operatorname{cl} 5(1)$

185 Law Commission, above n 21, at [115].

186 At [116]

187 Sentencing Amendment Act 2007, s 15

188 Young and King, above n 167, at 258.

189 Criminal Justice Act 2003 (UK), s 172. 
of inconsistency present at the lower levels of criminal sentencing. ${ }^{190}$ Furthermore, the implementation of guidelines that are merely advisory may be a regressive step, because at the moment the guideline judgments issued by the Court of Appeal are binding (by convention, despite being obiter dicta) on the lower courts. The Commission rightly indicated that replacing this position with the United Kingdom's approach "could thus weaken the relative consistency that currently exists in sentencing for the most serious offences". ${ }^{191}$ In other words, if the test for departure was too loose, or if the guidelines were only advisory in nature, the practical effect of the Sentencing Council may be to inadvertently create further inconsistency in the sentencing sphere.

\section{F Constitutional Uncertainties}

The Sentencing Council faced vehement criticism from opposition parties during its passage through Parliament. The National Party made it clear that it would repeal the legislation should it win the pending 2008 general election, ${ }^{192}$ with its concerns falling under two broad categories: that the Council impinged on judicial independence; and that its existence offended the doctrine of separation of powers.

\section{Judicial independence}

Underpinning National Party sentiment was the notion that constraining judicial discretion in sentencing with guidelines was an affront to judicial independence. ${ }^{193}$ This was echoed by organisations such as the Howard League for Penal Reform, who submitted that the Council "represents a departure from the convention of judicial independence ... [I]ts deliberations sentencing guidelines - will inevitably curtail judicial discretion". ${ }^{194}$

However, this represents a fundamental misunderstanding of the nature of judicial independence. Pankhurst J, writing extrajudicially, posited that: ${ }^{195}$

Judges must maintain responsibility for the imposition of sentences in individual cases. In doing so, the

constitutional independence of the judiciary is of fundamental importance. It provides the best assurance

190 Warren Young "Criminal Justice Reform Bill: Supplementary Briefing No 1" (presented to the Justice and Electoral Select Committee, 16 May 2007) (Obtained under Official Information Act 1982 Request to the Law Commission) at [20].

191 At [21].

192 See "National to scrap sentencing council" The National Business Review (New Zealand, 2 August 2008); and National Party "National will Cut Bureaucracy and give Funds to Victims of Crime" (press release, 2 August 2008).

193 (19 June 2007) 640 NZPD 10003.

194 The Howard League for Penal Reform "Submission to the Justice and Electoral Select Committee on the Criminal Justice Reform Bill" at [2.4].

195 Graham Pankhurst "A Sentencing Council: Enlightened or Folly?" (2007) 14 Canta L Rev 191 at 200. 
that sentences are not influenced by political or other considerations. But, the sentencing policy, or sentencing environment, under which individual sentences are imposed, is another matter. I would argue that sentencing policy is a concern of the entire community.

Judicial independence extends simply to deciding cases "without fear or favour, affection or ill will". ${ }^{196}$ Its importance in constitutional terms lies in the fact that judges need to be able to decide cases without interference from the other two branches of government. ${ }^{197}$ To this end there exists constitutional protections around judicial tenure ${ }^{198}$ and remuneration. ${ }^{199}$ Judicial independence does not mean that it is exclusively for judges to determine the overarching sentencing framework. ${ }^{200}$ While historically judges have indeed had a broad and unregulated discretion in the field of sentencing, ${ }^{201}$ parliamentary sovereignty makes it clear that such discretion can be constrained by the legislature setting maximum, mandatory or minimum sentences. It therefore follows that Parliament also has the power to implement sentencing guidelines of the kind in question, which simply further dictate the nature or range of penalties that can be implemented. ${ }^{202}$ The fact Parliament has not done so before this "is a matter of preference rather than constitutional principle". ${ }^{203}$ It is interesting to note that judges themselves do not view the Council as infringing on judicial independence in the way described. ${ }^{204}$

\section{Separation of powers}

Of perhaps greater concern to the National opposition was the impact the Sentencing Council may have on the separation of powers. Christopher Finlayson MP opined that "from time immemorial the separation of powers has been seen to be essential to our democracy, and this Parliament must zealously safeguard the separation of powers". ${ }^{205}$ His reservations, prima facie, have some legitimacy.

196 To quote the judicial oath. See Oaths and Declarations Act 1957, s 18.

197 See Philip Joseph Constitutional and Administrative Law in New Zealand (3rd ed, Brookers, Wellington, 2007) at [20.3.1]

198 Constitution Act 1986, s 23.

199 Section 24.

200 Law Commission, above n 21, at [43].

201 Hammond, above n 103, at 213.

202 Law Commission, above n 21, at [43].

203 Young and King, above n 167, at 258 .

204 Warren Young "Sentencing Reform in New Zealand: A Proposal to Establish a Sentencing Council" in Arie Freiberg and Karen Gelb (eds) Penal Populism, Sentencing Councils and Sentencing Policy (Willan Publishing, Devon, 2008) 179 at 188.

205 (19 June 2007) 640 NZPD 10003. 
It was Mr Finlayson's contention that the Council would have members of the judiciary undertaking functions that are more properly the role of the executive. For example, s 8(c) of the Sentencing Council Act would have the Council to produce guidelines that "inform members of Parliament and policymakers about sentencing and parole practice"; s 8(a)(iv) would have judges facilitating the provision of information to enable penal resources to be effectively managed; and $\mathrm{s}$ 9(d) would require them to give statements on the guidelines' likely effect on the prison population. These, according to Mr Finlayson, "are not legitimate functions of the judiciary". ${ }^{206}$ The judiciary also expressed concern, with the Chief Justice saying that what is proposed is a significant collaboration of the three separate branches of government to produce law, and that this is "right at the edge of what is constitutionally appropriate". ${ }^{207}$ She viewed the Council as having two distinct purposes: to promote consistency in sentencing, but also in the "setting of wider social policies through sentencing guidelines and the provision to the Executive of estimates about their impact on prison population". ${ }^{208}$ While the judiciary was well placed to assist in the former, the Chief Justice indicated that judges had much less to contribute in relation to the latter.

The judiciary ${ }^{209}$ recommended that the Bill therefore be modified to assuage concerns around the separation of powers. Changes included making it clear that the executive cannot give directions to the Council; making it clear that it is still the role of the government, not the Council, to manage penal resources; ensuring that the guidelines would indeed act simply as guidance, and would not dictate the outcome in a particular case; and to provide for a senior judge to chair the Council, who can ensure that judges are not co-opted into policy making beyond that which is consistent with the judicial function. ${ }^{210}$ All of these recommendations have since been adopted and are present, either implicitly or explicitly, in the Sentencing Council Act 2007.

Any lingering concerns that the Council would require its judicial members to be engaged in social policy functions that are more properly the role of the executive have been addressed by Dr Warren Young, who headed the project at the Law Commission. He claims that judges have always had a role in developing social policy through the common law, and that the existence of the Council "merely makes the role of judges in developing social policy more transparent". ${ }^{211}$ Furthermore, the contention that the Council will force judges to tackle fiscal issues is overstated, as their role is one step removed from actually implementing fiscal policy. The Council's consideration of prison populations and fiscal policy merely accompany the proposed guidelines, and aim to

206 (19 June 2007) 640 NZPD 10003.

207 Elias, above n 169, at [4].

208 At [4].

209 Thirty of the 41 Judges who participated in a session discussing the Criminal Justice Reform Bill.

210 Elias, above n 169, at [7].

211 Young and King, above n 167, at 258. 
ensure that public debate around their implementation can be fully informed. The decision over whether or not to approve the guidelines is ultimately one for Parliament, ${ }^{212}$ and there is no suggestion that the development of guidelines would have to conform to prison population or budgetary constraints determined by the Government. ${ }^{213}$

The Attorney-General also received advice from the Crown Law Office which concluded that a Sentencing Council would not be an affront to the separation of powers. ${ }^{214}$ Weight was placed on overseas jurisprudence, ${ }^{215}$ particularly the United States Supreme Court decision in Mistretta $v$ United States, ${ }^{216}$ where the Court held that the guidelines issued by the federal Sentencing Commission were not unconstitutional and that the Commission did not breach the principle of separation of powers. Justice Blackmun, who delivered the opinion of the Court, said that: ${ }^{217}$

Congress' decision to create an independent rulemaking body to promulgate sentencing guidelines and to locate the body within the Judicial Branch is not unconstitutional unless Congress has vested in the Commission powers that are more appropriately performed by the other Branches or that undermine the integrity of the Judiciary.

The Court went on to hold that the integrity of the judiciary was not undermined, nor were the Commission's functions more appropriately that of another branch of government. Like the United States, the functions of the New Zealand Sentencing Council have an executive "tinge", because they involve the "provision of policy advice, informing Members of Parliament and policy makers, and informing and educating the public". ${ }^{218}$ Whilst skirting close to the margins of the separation of powers, the Council is not unconstitutional as it remains an independent statutory body, and allows the judicial members to withdraw from participation in any of the Council's functions if they consider them to be incompatible with their judicial office. ${ }^{219}$

212 Mark Andrew Shaw, "Consistency versus Discretion - A Matter of Judgment? Hessell $v$ R and Judicial Sentencing Guidelines" (LLB(Hons) research paper, Victoria University of Wellington, 2011) at 10.

213 Young, above n 54, at 189.

214 Crown Law Office Legal Advice - Consistency with the New Zealand Bill of Rights Act 1990: Criminal Justice Reform Bill (ATT395/22, 20 November 2006).

215 Whilst rightly noting that care should be taken in in drawing comparisons with overseas jurisdictions, especially given the varied constitutional contexts that any Council would need to operate in.

216 Mistretta v United States 488 US 361 (1989).

217 At 385

218 Crown Law Office, above n 214, at [44].

219 Sentencing Council Act 2007, sch 1, cl 2(2). 


\section{Should the guidelines have retrospective effect?}

It is a long held principle of the criminal law that where a penalty has been increased between the commission of an offence and sentencing, the offender is entitled to the lesser of the two penalties. ${ }^{220}$ This is underpinned by various other fundamental tenets of the criminal law: the principles of strict construction, minimum criminalisation, maximum certainty and even the rule of law itself. ${ }^{221}$ The New Zealand judiciary has strived to uphold this principle of non-retrospectivity. The Court of Appeal has held that it is "at the forefront of a criminal justice system which is fair and just",222 and Williams $\mathrm{J}$ in the High Court said that non-compliance with the principle is "repugnant to justice". ${ }^{223}$ The legislature has enshrined the principle in both the Sentencing Act $2002^{224}$ and the Bill of Rights Act, ${ }^{225}$ the provisions of which are identical and guarantee the offender "the right, if convicted of an offence in respect of which the penalty has been varied between the commission of the offence and sentencing, to the benefit of the lesser penalty". This is consistent with New Zealand's international obligations, particularly under the International Covenant on Civil and Political Rights. ${ }^{226}$ Parliament has given primacy to this principle by legislating that it applies despite any other enactment or rule of law. ${ }^{227}$

However, the Law Commission recommended, and Parliament subsequently agreed, that the guidelines of the Sentencing Council be given retrospective effect. ${ }^{228}$ The Sentencing Amendment Act 2007 would require the sentencing judge to take into account an applicable guideline "whether or not the guideline was in force when the offence was committed". ${ }^{229}$ This is prima facie a contravention of the principle of non-retrospectivity, and means that offenders may be given a more punitive sentence under the guidelines than they would have received at the time they committed the offence.

220 Robertson, above n 50, at [SA6.01].

221 For an analysis of all of these principles, see Andrew Ashworth and Jeremy Horder Principles of Criminal Law (7th ed, Oxford University Press, Oxford, 2013) at 57.

$222 R$ v Poumako [2000] 2 NZLR 695 (CA) at [53].

$223 R$ v Pora (2000) 18 CRNZ 25p (HC) at 268.

224 Sentencing Act 2002, s 6(1).

225 New Zealand Bill of Rights Act 1990, s 25(g).

226 See International Covenant on Civil and Political Rights 999 UNTS 171 (opened for signature 16 December 1966, entered into force 23 March 1976), art 15(1).

227 Sentencing Act 2002, s 6(2).

228 Law Commission, above n 21, at [218].

229 Sentencing Amendment Act 2007, s 5. 
The matter was considered by the Crown Law Office when tendering advice to the AttorneyGeneral on the Criminal Justice Reform Bill's consistency with the Bill of Rights Act. ${ }^{230}$ It determined that there was no issue around the retrospective nature of the guidelines, basing their conclusion on the Supreme Court decision of Morgan v Superintendent of Rimutaka Prison. ${ }^{231}$ In Morgan, the majority of the Court had held that the protections found under s 25(g) of the Bill of Rights Act concerning retrospective penalties only relate to the variation of maximum penalties, and not to the individual sentence that might have been imposed on a particular offender. As such, the Crown Law Office said that "the retrospective nature of the sentencing and parole guidelines ... do not breach $\mathrm{s} 25(\mathrm{~g})$ of the BORA because the provisions do not change the maximum penalty able to be imposed for any offence". ${ }^{232}$

It is interesting to note that the Chief Justice, in a letter to the Justice and Electoral Select Committee, implored the members "to ensure that no adverse retrospective effect results from the adoption of any guidelines". ${ }^{233}$ The Law Commission, in a supplementary briefing paper to the Committee, acknowledged the comments of the Chief Justice, but pointed out that she had dissented in the Morgan case, and that her views are therefore inconsistent with the leading New Zealand decision on the issue. ${ }^{234}$ In the same paper, the Commission argued that the principle against the retrospective application of the criminal law is only triggered when offenders are prejudiced, and that in practice the guidelines would benefit a large number of offenders. ${ }^{235}$ For those offenders who would receive a more severe sentence from the imposition of an issued guideline, the Commission emphasised that a sentencing judge can depart from the guidelines as necessary on a case by case basis. 236

As a result, retrospectivity has been justified on the basis that in most situations the new guidelines will benefit offenders anyway. In those cases where it does not, the sentencing judge has discretion to depart from the guideline in the interests of justice. That said, the need for making the guidelines retrospective in the first place has not been clearly enunciated, and the constitutionality of the Council may be improved by dropping the requirement altogether.

230 Crown Law Office, above n 214.

231 Morgan v Superintendent of Rimutaka Prison [2005] NZSC 26, [2005] 3 NZLR 1.

232 Crown Law Office, above n 214, at [10].

233 Elias, above n 169.

234 Young, above n 190. It should be noted that the Chief Justice was not speaking in a personal capacity, but on behalf of a number of judges that had been consulted on the Bill.

235 At [9].

236 At [13]. 


\section{Hessell v R - Supreme Court attack on the guidelines}

In 2009, the New Zealand Court of Appeal took the opportunity to issue a guideline judgment on the appropriate level of discount that sentencing judges should apply for an early guilty plea. ${ }^{237}$ Until that point the Court had been reluctant to lay down any specific quantum for a discount, ${ }^{238} \mathrm{a}$ situation which Chambers $\mathbf{J}$ described as "symptomatic of the courts' general approach to sentencing, with judges vested with broad discretions". ${ }^{239}$ Although there had been a slow shift towards more definitive guidelines on the issue since $2005,{ }^{240}$ spurred on by $\mathrm{s} 8(\mathrm{e})$ of the Sentencing Act 2002, ${ }^{241}$ as well as a relevant guideline issued by the Sentencing Guidelines Council in the United Kingdom, ${ }^{242}$ in practice this had only served to muddy the waters even further. Chambers $\mathbf{J}$ said that a guideline judgment clarifying the position in New Zealand would have been issued earlier, but the Court was expecting the situation to be remedied by the Sentencing Council instead. However, as it was apparent that the National-led Government was not going to establish the Council in practice, the Court of Appeal resolved to resume their programme of issuing guideline judgments. $^{243}$

In constructing their judgment, the Court of Appeal placed considerable weight on the draft Guilty Pleas Guideline that had been formulated by the Sentencing Establishment Unit at the Law Commission as part of the inaugural sentencing guidelines. ${ }^{244}$ It also looked at the equivalent guideline that had been implemented by the Sentencing Guidelines Council in the United Kingdom, which Chambers $\mathbf{J}$ noted as having the same methodology as the New Zealand draft iteration. ${ }^{245}$ The full bench of the Court of Appeal decided that the Law Commission's recommended approach (and, by extension, the approach in the United Kingdom) was "most desirable", ${ }^{246}$ and implemented

237 Hessell v R [2009] NZCA 450, [2010] 2 NZLR 298.

238 See $R v$ Mako, above n 36, at [14].

239 Hessell $v R$, above $\mathrm{n} 237$, at [2].

240 See $R v$ Hannagan CA396/04, 9 June 2005; and $R v$ Growden CA67/05, 25 October 2005.

241 This section requires the court to "take into account the general desirability of consistency with appropriate sentencing levels and other means of dealing with offenders in respect of similar offenders committing similar offences in similar circumstances".

242 Sentencing Guidelines Council "Reduction in Sentence for a Guilty Plea: Definitive Guideline" (United Kingdom, July 2007).

243 Hessell $v$ R, above $\mathrm{n} 237$, at [5].

244 Sentencing Establishment Unit Confidential Draft Guideline "Guilty Pleas" (July 2008) (Obtained under Official Information Act 1982 Request to the New Zealand Law Commission).

245 Hessell $v$ R, above $\mathrm{n} 237$, at [8].

246 At [10]. 
it accordingly. ${ }^{247}$ An intricate analysis of the guideline falls outside the scope of this article. It is enough to say that the Court of Appeal adopted a sliding scale of discount which turned on when the guilty plea was delivered; subsumed remorse as a mitigating factor into the guilty plea discount; and held that the strength of the prosecution case was an irrelevant consideration when determining the quantum of reduction.

The decision was subsequently appealed, with the Supreme Court granting leave on the grounds of "whether the discount for [the applicant]'s guilty plea was appropriately given in accordance with sentencing principles and the Sentencing Act 2002". ${ }^{248}$ The judgment of McGrath J, on behalf of a unanimous bench, was scathing of the Court of Appeal. ${ }^{249}$ Although it did not attack the Law Commission guideline directly, for all intents and purposes an attack on the Court of Appeal's judgment was an attack on the validity of the draft guideline itself. McGrath J said that the Court of Appeal had "underestimated the complexity of the issue" before them, ${ }^{250}$ noting that the approach adopted "would put pressure on an accused to plead guilty for reasons that are unprincipled", and thus created an "unacceptable risk" that innocent persons would plead guilty. ${ }^{251}$ Indeed, all aforementioned aspects of the guideline judgment were criticised and revised by the Supreme Court.

Mark Shaw says that this is a reflection on the efficacy of the Sentencing Council, and indicates that (at least in the Supreme Court's view) the "sentencing councils may produce guidelines that are incompatible with basic criminal justice principles". 252 This may be unduly strong language, especially considering that the draft guideline received significant input from the High Court judiciary at the Law Commission's Sentencing Establishment Unit. Nevertheless, it is proof that not all of the issued guidelines will be accepted by the judiciary, despite there being judicial input in their development. This is a major blow to any future attempts at establishing the Sentencing Council in practice, because it may be indicative of a lack of "buy in" from the top levels of the New Zealand judiciary - something the Law Commission considered to be essential to the Council's success. ${ }^{253}$ In light of this decision one can infer that the Supreme Court would have no reservations about attacking guidelines that it considers to be inconsistent with the Sentencing Act, which was the "ultimate difficulty" they had with the Court of Appeal's approach. ${ }^{254}$ This problem would be

\author{
247 At [22]. \\ 248 Hessell $v R$ [2010] NZSC 40. \\ 249 Hessell $v$ R [2010] NZSC 135, [2011] 1 NZLR 607. \\ 250 At [67]. \\ 251 At [60] and [72]. \\ 252 Shaw, above n 211, at 14. \\ 253 Law Commission, above n 21, at [83]. \\ 254 Hessell $v \mathrm{R}$, above $\mathrm{n} 249$, at [67].
}


exacerbated by the statutory requirement that the guidelines produced by the Council be consistent with the Sentencing Act. ${ }^{255}$ A soft form of judicial strike down of unacceptable guidelines could occur, whereby the upper levels of the judiciary interpret the guidelines so narrowly that they lose their desired effect.

It is interesting to note that the affidavit evidence of several Crown Solicitors indicated that the Court of Appeal's guideline judgment on guilty pleas was not being evenly applied in the District Courts anyway. McGrath $\mathrm{J}$ said that in some regions "considerable latitude" was being extended to defendants to receive the full discount of 33 per cent, irrespective of where they fell on the Court of Appeal's sliding scale, so long as the plea was entered before committal. ${ }^{256}$ More substantive research to establish the veracity of these claims is clearly necessary, but it prima facie indicates that the implementation of the draft guideline prepared by the Law Commission would have had little effect in achieving consistency, which was overriding purpose of a Sentencing Council in the first place.

\section{Fitzgerald v Muldoon - A modern day breach?}

The Sentencing Council Act has been on the statute books for over seven years, but the Council itself has yet to be established in practice. It is still awaiting the Executive Council to tender advice to the Governor-General, so that the body can be brought into force through Orders in Council. ${ }^{257}$ Some commentators believe that this raises "serious constitutional issues", ${ }^{258}$ as it is possible that the Government's failure to make the Act operative is illegal, relying on the authority of Fitzgerald $v$ Muldoon. ${ }^{259}$ At its most basic, the situation may amount to the executive refusing to implement laws passed by the legislature.

In Fitzgerald v Muldoon, the Supreme Court held that the Prime Minister had acted unlawfully when he unilaterally abolished the New Zealand Superannuation Scheme established by the Superannuation Act 1974. His actions contravened s 1 of the Bill of Rights Act 1688, which says that "the pretended power of suspending of laws, or the execution of laws, by regal authority without consent of Parliament, is illegal". Only Parliament has the ability to make or unmake laws, and the executive does not have the power to override or set aside the legislation of Parliament. ${ }^{260}$

\footnotetext{
255 Sentencing Council Act 2007, s 9(1)(a).

256 Hessell $v$ R, above $\mathrm{n} 249$, at [68].

257 Sentencing Council Act 2007, s 2.

258 Palmer, above n 82, at 614.

259 Fitzgerald v Muldoon [1976] 2 NZLR 615 (SC).

260 At 622 .
} 
Can the current Government's inaction in implementing the Sentencing Council fall under this precedent? It is difficult. The precedent can immediately be distinguished on its facts: in Fitzgerald $v$ Muldoon, the Prime Minister was suspending a law that was already functioning; here, the executive is failing to bring an Act into force. Indeed, the legislature has bestowed upon the executive a degree of discretion as to when the Sentencing Council will actually be implemented, as $\mathrm{s} 2$ of the Act dictates that it is to be brought into force through Orders in Council. This is consistent with Standing Orders, ${ }^{261}$ thus adding a degree of legislative legitimacy. Alec Samuels agrees, saying that it is constitutionally acceptable for a statute not to have been brought into force after a very long delay, because: ${ }^{262}$

... subject to any express provision to the contrary, the minister has a discretion whether or not to make

an order but, nonetheless, he is under a duty to keep the situation under review.

There is no indication that the Government has reviewed the need for a Sentencing Council in New Zealand, having issued no statement around the Council's existence since its election campaign in 2008. The legislature would not pass legislation simply to have it languish indefinitely in abeyance between royal assent and Order in Council. If the Government is not happy with the Act and has no intention of implementing it, then it should introduce a Bill to Parliament to repeal it. It has not done so. There is therefore an arguable case for saying that the Government has in effect suspended the law without proper authority.

\section{CONCLUSION}

Criminal sentencing is one of the most difficult and complex components of the legal system. This was aptly articulated by McArdle J, who said that "trying a case is as easy as falling off a log. The difficulty comes in knowing what to do with an accused once they have been found guilty." 263 Underlying this difficulty is a fundamental tension between individualised justice and consistency. Judges must be given some degree of discretion to tailor a sentence that is appropriate on the facts of the particular case, but at the same time, mechanisms need to exist to ensure that like cases are treated alike. Finding the correct equilibrium is of fundamental importance, as it ensures the integrity and legitimacy of the criminal justice system.

New Zealand has not yet found this equilibrium. There is a growing body of evidence highlighting extensive regional variations in sentences imposed, indicating that appellate guideline judgments, and the principles and purposes of sentencing, are insufficient to ensure consistency. The

261 Standing Orders of the House of Representatives 2014, SO 256.

262 Alec Samuels "Repealing or Amending Legislation by Non-Legislative Means" in Constantin Stefanou and Helen Xanthaki (eds) Drafting Legislation: A Modern Approach (Ashgate Publishing Ltd, Hampshire, 2008) 107 at 109.

263 Geoff Hall Sentencing: 2007 Reforms in Context (Lexis Nexis, Wellington, 2007) quoting McArdle J at 1. 
"dragon of arbitrary discretion" clearly needs a shorter leash. ${ }^{264}$ This would not be achieved by the intuitive synthesis approach to sentencing, which amounts to removing the leash entirely. Although this is the method used in some jurisdictions in Australia and Canada, it should not be followed in New Zealand as it removes much of the transparency in sentencing and in many ways normalises disparity. The approach also requires the existence of an overriding purpose of sentencing, or at least a clearly defined hierarchy thereof, of which New Zealand has neither. An alternative mechanism would be to introduce mandatory sentences, which would swiftly slay the dragon. Mandatory sentences may technically achieve consistency, but they come at the cost of individualised justice. The result would be for dissimilar cases to be treated alike, which is no better than the original problem that required fixing. Such an approach would also merely transfer discretion from judges to police and prosecutors, effectively giving less accountable bodies a greater role in the imposition of sentences. Furthermore, research in the United States suggests that prosecutors will lay less severe charges in order to mitigate against what could otherwise be an incredibly punitive system.

It is clear then that the solution to the problem of inconsistent sentencing does not lie at the extremities. Indeed, the answer has been in plain sight since 2007, when the Sentencing Council Act was passed. The implementation of a Sentencing Council with a mandate to draft guidelines is the best way forward for New Zealand's criminal justice system. The expertise and resources of the Council would ensure that coherence could be given to sentencing as a whole, leaving behind the piecemeal approach that currently exists in the form of appellate guideline judgments. Furthermore, the Council can fully cost all of its recommendations and forecast their likely effect on the prison population, which would in turn give the Government increased control over the Corrections budget. While there is a presumption that the guidelines would be followed, the proposed public interest test for departure would ensure that there is flexibility for sentencing judges to depart from the guidelines as necessary - finally achieving the desired equilibrium between individualised justice and consistency.

That said, the fate of the Sentencing Council looks dire. With the re-election of the centre-right National Party in 2014, the Act is likely to continue to wallow on the statute books or find itself repealed entirely. Repeal would be a bold move, as sentencing councils are becoming the norm in a range of comparable overseas jurisdictions. Furthermore, significant consultation went into the Act's creation, receiving support from both the Law Commission and members of the wider judiciary. If the Sentencing Council Act is not implemented then careful consideration must be given by the Government around what to replace it with, because the sentencing regime in New Zealand as it stands is unsatisfactory. A justice system that fails to ensure fairness and consistency will not long be worthy of the name. 
